\title{
The Agricultural Bone of Contention: The Franco-German Tandem and the Making of the CAP, 1963-1966
}

\section{Carine GERMOND}

Agriculture is one of the economic sectors where the process of European integration has been carried furthest. Mentioned in very broad terms in the Rome Treaty of 1957 establishing the European Economic Community (EEC), the Common Agricultural Policy (CAP) was gradually set up during the 1960s. In January 1962, the Common Market countries agreed that the CAP would be organized around the core principles of market unity, Community preference and financial solidarity. In the first half of the 1960s, common prices for each product were adopted and common market organisations created. The common agricultural market became fully implemented in the summer of 1967.

The creation of a common agricultural policy posed specific problems for France and Germany. As one of the principal producers and exporters of agricultural products, France was the state which had most to gain from the formation of a common agricultural market. In the early 1960s, agriculture remained a key economic sector. About 20 percent of the active population worked in that sector and agriculture represented around 10 percent of France's gross domestic product. Hence, when Charles de Gaulle returned to power in 1958, agricultural integration became "a sine qua non condition of France's participation to the EEC". ${ }^{1}$ Thanks to the CAP, de Gaulle hoped to adapt France's industrial and agricultural sectors to the new conditions of trade and competition in the Common Market, ${ }^{2}$ to solve overproduction and social problems in agriculture, ${ }^{3}$ and finally to maintain France's economic parity with Germany - a prerequisite to safeguard its senior position in the Franco-German tandem. For the Federal Republic of Germany (FRG), a major agricultural importer, the CAP threatened to disrupt the German traditional commercial links with third countries, where the FRG bought agricultural commodities and traded manufactured goods. Thus, the German dilemma was to continue buying agricultural commodities to its traditional clients while guaranteeing a certain preference to its EEC partners in its own market. ${ }^{4}$ The CAP also represented a challenge for the highly subsidized and relatively inefficient German agriculture. In addition, although farmers encompassed

1. C. de GAUlle, Mémoires d'espoir, t.I, Paris, Plon, 1970, p.167. See also M. COUVE DE MURVILLE, Une politique étrangère (1958-1969), Plon, Paris, 1971, p. 313.

2. E. PISANI, Le Général indivis, Albin Michel, Paris, 1974, p.63.

3. W.F. ROY, France, Germany and the New Europe 1945-1967, Stanford University Press, Stanford, 1968, p.287.

4. Archives Diplomatiques, Ministère des Affaires étrangères [AD/MAE], Europe [EU] 1961-1970, sous-série [s/s RFA], vol.1552, A. de Saint-Mleux à M. Couve de Murville, Munich, 16.03.1966. 
only 10 percent of the German active population in the 1960s, they were well organized and represented a non-negligible electoral support for the Christian Unions. ${ }^{5}$

Focusing upon France and Germany in an analysis of a Community policy makes more sense in state-centric than in supranational explanations of European integration, ${ }^{6}$ which represent the two main strands in the historiography of European agricultural integration. Whereas historical studies on the CAP have traditionally adopted a state-centric approach in line with the then predominant realist paradigm of European integration history, ${ }^{7}$ recent studies on the CAP have stressed the supranational (and transnational) dimensions of the policy. ${ }^{8}$ While acknowledging the new insights brought by these works, this paper argues that examining the issue through a FrancoGerman lens can lead to a greater understanding of constitutive bargains and history making decisions in certain key policy areas such as agriculture. Yet, historical studies on the role of France and Germany in agricultural integration are either older ${ }^{9}$ or focus primarily on the $1950 \mathrm{~s} .{ }^{10}$ Some of the most recent historical studies have touched upon Franco-German relations but only provide a partial picture of bilateral interactions. ${ }^{11}$ This article intends to address this gap in the literature by providing a detailed account of Franco-German relations and their influence on the setting-up of the CAP based on French and German archives.

This article analyses to what extent the two countries' disagreements on the economic (and institutional) developments of the EEC were responsible for the repeated crisis that broke out on agricultural matters during the first half of the 1960s, and assesses the effects of Franco-German institutionalized bilateralism on European in-

5. P. GERBET, La construction de l'Europe, La documentation français, Paris, $2007^{4}$, p. 254.

6. A. COLE, Franco-German Relations: From Active to Reactive Cooperation, in: J.E. HAYWARD (ed.), Leaderless Europe, Oxford University Press, New York, 2008, p.162. See also D. WEBBER, Franco-German Bilateralism and Agricultural Politics in the European Union: The Neglected Level, in: West European Politics, 1(1999), pp.45-67.

7. See for instance A.S. MILWARD, The European Rescue of the Nation-State, Routledge, London, 20002; A. MORAVSCSIK, De Gaulle between Grain and Grandeur. The Political Economy of French EC Policy 1958-1970, in: Journal of Cold War Studies, 2 and 3(2000), pp.3-43 \& 4-68; G. HENDRICKS, Germany and the CAP: National Interests and the European Community, in: International Affairs, Winter(1988-1989), pp.75-87; U. KLUGE, Vierzig Jahre Agrarpolitik in der Bundesrepublik, P. Parey, Hamburg, 1989; K.K. PATEL, Europäisierung wider Willen. Die Bundesrepublik Deutschland in der Agrarintegration der EWG 1955-1973, Oldenburg, München, 2009. See also the contributions of Laurent Warlouzet and Kiran Klaus Patel in: K.K. PATEL (ed.), Fertile Ground for Europe? The History of European Integration and the Common Agricultural Policy, Nomos, Baden-Baden, 2009, pp.99-117, 139-160.

8. See in particular N.P. LUDLOW, The Making of CAP: Towards A Historical Analysis of the EU'S First Major Policy, in: Contemporary European History, 3(2005), pp.347-371; N.P. LUDLOW, The European Community and the Crises of the 1960s. Negotiating the Gaullist Challenge, Routledge, Abingdon, 2006; A.C.L. KNUDSEN, Farmers on Welfare. The Making of Europe's Common Agricultural Policy, Cornell University Press, Ithaca, 2009. See also the contributions of N.P. LUDLOW, K. SEIDEL in: K.K. PATEL (ed.), Fertile Ground ..., op.cit., pp.79-96, 161-179.

9. W.F. ROY, op.cit.

10. G. NOËL, France, Allemagne et "Europe verte", Peter Lang, Berne, 1995.

11. See N.P. Ludlow, The European Community ..., op.cit.; A.C.L Knudsen, Farmers on Welfare ..., op.cit. 
tegration. The first section examines Franco-German negotiations in the run-up to the two crucial agricultural marathons of December 1963 and December 1964. The second section investigates the role of France and Germany in the outbreak and the resolution of the empty chair crisis of 1965-1966.

\section{The Agricultural Marathons of December 1963 and 1964}

When Ludwig Erhard succeeded to Konrad Adenauer as German Chancellor in October 1963, he inherited the agricultural problem. In January 1962, the Six had laid the foundation for the organization and financing of the CAP through the establishment of a mechanism of price support and the creation of the European Agricultural Guarantee and Guidance Fund (EAGFF), and set precise deadlines for the gradual completion of the policy. Yet, the discussions on the British membership application to the EEC and the breakdown of the negotiations following Charles de Gaulle's press conference on 14 January 1963 had delayed the adoption of various market regulations. The synchronization plan presented by the German Foreign Minister Gerhard Schröder in April 1963 allowed the Six to resume work in the Community and set out the timely conclusion of agricultural negotiations before the end of the year.

The new Federal government was all but supportive of the CAP, however. Erhard, the former and long-time Minister for Economics, was a vocal opponent of the CAP, whose protectionism and artificial support of non-viable agricultural farms he criticized. Moreover, two other key members of the first Erhard Cabinet, Foreign Minister Gerhard Schröder and Agricultural Minister Werner Schwarz, were also outright critics of the Community's flagship policy.

The coming to power of Erhard coincided with the publication of new proposals by the European Agriculture Commissioner Sicco Mansholt for the harmonization of cereal prices "in einem Zuge" 12 and the establishment of common cereal prices at an intermediate level between the French and the German prices - i.e. between the lowest and the highest price in the EEC - on 4 November 1963. The French and German reactions to the Commission's proposals stressed their differing interests.

The French considered that the Commission's proposals were "un élément de consolidation et d'accélération de l'intégration dans le domaine agricole". ${ }^{13}$ Yet, the terms of the harmonization of prices were problematic. ${ }^{14}$ Paris feared that a price

12. Politisches Archiv des Auswärtigen Amtes [PAAA], Berlin, B 1, Bd.210, Maßnahmen zur Herstellung eines gemeinsamen Getreidepreises/Begründung der Vorschläge der Kommission an den Rat, EWG-Kommission, Brüssel, 04.11.1963.

13. AD/MAE, Papiers des directeurs, s/s Olivier Wormser [PD-OW], vol.2, Note du SGCI sur la proposition Mansholt relative au rapprochement du prix des céréales, Paris, 15.11.1963.

14. The SGCI anticipated that the Mansholt proposition could raise price levels in France, lead to an excessive use of compensatory subsidies and to a destabilization of the financial regulation. $\mathrm{AD} /$ MAE, DECE, vol.1150, Note a/s politique agricole commune/propositions "Mansholt" relatives aux prix des céréales, Paris, 12.11.1963. 
level that would be set too high would have inflationary effects in France and would jeopardize the stabilization plan adopted months earlier. ${ }^{15}$ The reception of the Mansholt plan was more critical in Germany. Despite considerable income compensations for the member states (Germany, Italy and Luxembourg) that were to lower their prices as a consequence of the common price, the proposals were problematic because they would accelerate the completion of the common agricultural market without guaranteeing parallel progress in other areas. Bonn wanted to synchronize integration in the agricultural and industrial sectors, however. Since the German agreement to a common price was, according to the director of the political service at the German Foreign Ministry, "der letzte Trumpf, den wir in der EWG noch ausspielen können, wir sollten unsere Zustimmung gegen Zusicherung in anderen Bereiche der Integration abkaufen lassen". ${ }^{16}$ In addition, these assurances should be significant enough to compensate the important domestic difficulties that an increase of the German cereal price would create. ${ }^{17}$ The Auswärtiges Amt also rightly expected that the DBV would reject the Mansholt proposals. Hence, Erhard affirmed in his governmental declaration that he would be "ein fairer Sachwalter der Interessen der deutschen Landwirtschaft", ${ }^{18}$ and defend the German cereal price level because he did not want to jeopardize the farming vote. At the same time, the German Chancellor suggested to Paris that he was not completely hostile to a compromise. Accordingly, the French objective was

"d'inspirer confiance au nouveau chancelier quant à notre volonté de faire aboutir la négociation tarifaire [within the General Agreement on Tariffs and Trade (GATT)], dès l'instant où une solution équitable et équilibrée fondée sur une réciprocité réelle des sacrifices consentis de part et d'autre aura été dégagée dans le domaine industriel et agricole". ${ }^{19}$

The French strategy vis-à-vis the Erhard administration thus consisted of two main elements. First, Paris intended to make progress in the new round of GATT negotiations conditional on progress in the CAP. ${ }^{20}$ The negotiations were scheduled to open in May 1964 and Bonn was particularly interested in their successful outcome. Second, the French government did not want to give the Germans an excuse to reject the

15. A. PEYREFITTE, C'était de Gaulle. La France redevient la France, vol.II, Fayard, Paris, 1997, p. 249.

16. PAAA, B 2, Bd.128, Jansen betr. Vorschläge der Kommission zur Getreidepreisannäherung, Bonn, 04.11.1963.

17. PAAA, B 130, Bd.2102, Aufzeichnung betr. Vorschläge der EWG-Kommission zur Angleichung der Getreidepreise/hier: Frage einer Kompensation für deutsche Zugeständnisse, Bonn, 07.11.1963.

18. K. HOHMANN, G. SCHRÖDER (Hrsg.) Ludwig Erhard. Gedanken aus fünf Jahrzehnten, Reden und Schriften, Econ Verlag, Düsseldorf, 1988, p.844.

19. AD/MAE, PD-OW, vol.2, Note a/s des négociations au GATT/Position allemande, 16.11.1963.

20. For an extensive account of the interplay between the Kennedy Round and the CAP, see L. COPPOLARO, Trade and Politics Across the Atlantic: the European Economic Community (EEC) and the United States of America in the GATT Negotiations of the Kennedy Round (1962-1967), European University Institute, Florence (unpublished Phd), 2006; N.P. LUDLOW, The Emergence of a Commercial Heavy-Weight: the Kennedy Round Negotiations and the European Community of the 1960s, in: Diplomacy and statecraft, 2(2007), pp.351-368. 
outstanding market regulations on rice, beef and dairy products to be adopted in December $1963 .^{21}$

During Erhard's first visit to Paris as Chancellor on 22-23 November 1963, agricultural issues stood at the top of the agenda. Pressed by the French to take a stand on the impending agricultural negotiations in Brussels, Erhard guaranteed that Germany would not pursue "une tactique de retardement". ${ }^{22}$ Yet, on 9 December the German delegation rejected the adoption of the regulation on rice and Schwarz even suggested that an agreement on dairy products was unlikely to happen since it would suppress subsidies for the German farmers. To Paris, this meant that Germany would not fulfil its agricultural commitments.

As a result, the French diplomacy put pressures on the Federal authorities. The French Ambassador in Bonn, Roland de Margerie, informed Erhard that Paris would delay the Kennedy Round of GATT talks until Germany fulfilled its obligations in the agricultural sector. ${ }^{23}$ Yet, Erhard's hands were tied as he had promised the leader of the DBV, Edmund Rehwinkel, that he would not agree to any lowering of the income of farmers. Erhard's change of heart had two main motives. First, the Chancellor understood that the harmonization of cereal prices was necessary for the establishment of a common agricultural market, but he could not ignore the electoral consequences that a lowering of the German farmers' income would have for his party, the Christian Democratic Union (CDU), which was dependent on the farmers' vote for the 1965 elections. As a result, the Federal government hoped to delay a decision on the cereal price for as long as possible. The second reason related to Erhard's lack of political leadership and his difficulties in reconciling the divergent positions of the Ministries of Agriculture and Economics, both of which had close links with influent professional organizations - the DBV for the Ministry of Agriculture $^{24}$ and the Bund der deutschen Industrie (BDI) for the Ministry of Economics. Finally, there also existed divergent viewpoints inside the Auswärtiges Amt: Schröder rejected any compromise with France whereas State Secretary Rolf Lahr advocated in favour of negotiations with Paris in hopes of obtaining French concessions in the industrial sector and the Kennedy Round. ${ }^{25}$

Margerie soon realized that his warnings were not taken seriously. As a result, French Foreign Minister Maurice Couve de Murville called on the German Ambas-

21. AD/MAE, DECE, vol.1150, Note a/s négociabilité des politiques agricoles, $\mathrm{n}^{\circ} 271 / \mathrm{Ce}, 15.10 .1963$. H. OSTERHELD, Außenpolitik unter Bundeskanzler Ludwig Erhard. Ein dokumentarischer Bericht, Droste Verlag, Düsseldorf, 1992, p.42.

22. AN, 5AG1/161, Entretien élargi entre Georges Pompidou et le chancelier Erhard le 21.11.1963, 30 novembre 1963.

23. AD/MAE, PD-OW, vol.2, Wormser to Margerie, 10.12.1963; AAPD, 1963 III, Dok.463, pp. 1611-1614.

24. See P. ACKERMANN, Der deutsche Bauernverband im politischen Kräftespiel der Bundesrepublik. Die Einflussnahme des DBV auf die Entscheidung über den europäischen Getreidepreis, J.C. Mohr, Tübingen, 1970, pp.77-79; E. FREISBERG, Die grüne Hürde Europas. Deutsche Agrarpolitik und EWG, Westdeutscher Verlag, Köln/Opladen, 1965, pp.45-47.

25. H. KRONE, Tagebücher, Bd.2.: 1961-1966, Droste, Düsseldorf, 2003, pp.252, 255. 
sador, Manfred Klaiber, to whom he made clear that "un report voire un échec des présentes négociations agricoles de Bruxelles aurait les plus graves conséquences pour le Marché commun". ${ }^{26}$ The threat that France would block or even leave the Community was not explicitly stated but it was an implicit warning. Either hypothesis was in fact closely examined by Olivier Wormser, head of the economic and financial service at the Quai d'Orsay. Wormser suggested three possible options in the event that Germany would not fulfil its commitments in December: first, France could distance itself from the Community, either by leaving its seat empty - Wormser appears here as a spiritual father of the empty chair policy -; second, France could refuse to pay its national contribution to the Community's budget, or third, block all decisions related to the GATT negotiations. ${ }^{27}$ The latter was especially problematic for Bonn as the EEC was in the process of defining a common position. In any event, Wormser's note was characteristic of the growing exasperation of Paris towards Bonn and its increasing fear regarding the outcome of the Brussels negotiations.

A few days before the opening of the agricultural negotiations, the French diplomats delivered a series of warnings. De Gaulle encouraged Alain Peyrefitte, the government's spokesperson, to announce that the French Cabinet could meet before Christmas if "un évènement impose d'en faire un, en particulier l'impossibilité d'aboutir à Bruxelles". ${ }^{28}$ Wormser informed Commission President Walter Hallstein that France would distance itself from the Common Market if the outstanding regulations were not approved by the end of the year. ${ }^{29}$ The Auswärtiges Amt also registered alarming rumours, orchestrated by the Elysée, ${ }^{30}$ according to which France had an alternative policy should negotiations fail. ${ }^{31}$ On 21 December 1963, Margerie met Erhard again while de Gaulle received the German ambassador. Both made clear that the non-adoption of the agricultural regulations by the end of 1963 would severely alter Franco-German relations and cast doubt over France's participation in the Common Market. ${ }^{32}$ De Gaulle reckoned that Erhard

"ne veut peut-être pas commencer sa carrière de chancelier comme celui qui aura cassé à

la fois le Marché commun et le traité franco-allemand". ${ }^{33}$

His political gamble succeeded. Erhard eventually agreed on 23 December to the three outstanding regulations because he was afraid that the French President carry out his threats and was anxious to preserve Germany's political credibility.

France and Germany were both satisfied with the December agreement, which relied on a bilateral compromise. By consenting to the regulations on beef, rice and

26. AAPD, 1963 III, Dok.469, pp.1628-1629.

27. AD/MAE, PD-OW, vol.50, Note a/s des négociations de Bruxelles, 18.12.1963.

28. A. PEYREFITTE, C'était de Gaulle ..., II, op.cit., p.255.

29. AD/MAE, PD-OW, vol.36, Note a/s négociations de Bruxelles, 28 décembre 1963.

30. A. PEYREFITTE, C'était de Gaulle ..., II, op.cit., pp.246, 255.

31. PAAA, B 150, Bd.19, Klaiber to Schröder and Lahr, Paris, 20.12.1963.

32. Documents diplomatiques français [DDF], 1963 II, 253; AAPD, 1963 III, Dok. 482, pp.1667-1668; «Tous mes adieux sont faits», mémoires inédites de Roland de Margerie, enveloppe n`5, 21.12.1963.

33. A. PEYREFITTE, C'était de Gaulle ..., II, op.cit., p.253. 
milk - thus the creation of markets organisations for these products -, Bonn no longer stood in the way of the further organization of the common agricultural market. At the same time, Paris had also given satisfaction to Germany by agreeing on the first elements of a common position of the EEC at the GATT negotiations. Yet, the previous bilateral tensions had left scars. Erhard, with his constant hesitations and uturns, was no longer a credible partner. The French government was increasingly annoyed with "la persistante mauvaise volonté des Allemands" and "un désir inavoué de retarder tout progrès agricole jusqu'à la fin de la négociation [du GATT]". ${ }^{34}$ Moreover, the December agreement, which Raymond Aron labelled "une victoire de l'idée européenne", ${ }^{35}$ was only possible because the Six had postponed the most difficult decision on the harmonization of cereal prices to the first half of 1964.

The definition of common cereal prices was of central importance to the completion of the CAP. Not only did it determine the level of many other agricultural commodities, but France, which produced about half of the EEC's cereals ${ }^{36}$ had a particular interest in this issue. It also raised a specific Franco-German quandary as the price set by the Mansholt plan of November 1963 meant an increase of the French cereal price of about 9 percent and a lowering of the German one of 11 to 15 percent with substantial economic and political consequences in both countries. ${ }^{37}$ As a result, Paris and Bonn agreed to postpone the application of Mansholt's proposals on the harmonization of the cereal price, although for different reasons.

The German government was still reluctant to adopt a common price, which would significantly cut German farm incomes, a politically highly sensitive issue for both the federal authorities and the DBV. Consequently, the Erhard administration played for time. Postponing a decision on a common price until the end of the second transition period - that is after 1966 - presented the additional advantage that the decisions would no longer be taken by unanimity but by qualified majority in the Council of Ministers. The Federal government could then argue that it had defended the interests of German farmers but was forced to accept the majority's viewpoint. This strategy was economically less attractive - a common price adopted by qualified majority would be lower than one adopted by unanimity - but it was politically advantageous since the German government could get over the 1965 elections without alienating the farmers' votes.

Paris was also interested in a postponement of the Mansholt proposal. The price level suggested by Mansholt was deemed too high and threatened to jeopardize the effectiveness of the stabilization plan. Paris also expected that a high price level would

34. M. COUVE DE MURVILLE, op.cit., pp.323-324.

35. R. ARON, Les articles de politique internationale dans le "Le Figaro" de 1947 à 1977, t.II: La coexistence, Editions de Fallois, Paris, 1993, p.1300.

36. A. PRATE, La France en Europe, Economica, Paris, 1995, p.68.

37. PAAA, B 130, Bd.2102, Aufzeichnung betr. Vorschläge der EWG-Kommission zur Angleichung der Getreidepreise, 07.11.1963. 
encourage overproduction in the EEC with problematic consequences for the Community budget. ${ }^{38}$ Moreover, an adjournment was considered a tactical trump, since

"une décision rapide $[\ldots]$ nous priverait vis-à-vis des Allemands d'un moyen de pression utile pour freiner leur appétit de compromis dans la partie industrielle de la négociation au GATT" 39

Conversely, a postponement presented two major drawbacks: first, common prices were an essential prerequisite for the completion of the CAP and, second, General de Gaulle wanted the realization of the policy to be achieved before the replacement of unanimity votes by qualified majority voting, which could give CAP-critic EC partners the possibility to revise the policy.

The following months reinforced Bonn's opposition to the Mansholt plan. On 19 March, during a debate on agricultural issues, Erhard, pressured by the DBV, was forced to reiterate his commitment to defend the German cereal price level for 1965 and $1966 .{ }^{40}$ The resolution adopted at the end of the debate, which rejected the fixing of a common cereal price before 1970 and linked it with a series of prerequisites, meant that Schwarz would continue his obstruction policy in Brussels.

Neither the French nor the Germans were keen on seeing the Mansholt plan adopted as it had been presented in November 1963. The Six thus asked the Commission to submit a revised version. In May, de Gaulle declared to a surprised Lahr that he understood Germany's difficulties regarding the common cereal price and repeated that "la France n'est pas pressée". ${ }^{41}$ The postponement of the GATT negotiations accounted for France's sudden benevolence. The delay made a decision on the cereal price less urgent as France could still use these negotiations to pressure Bonn on the CAP.

Given the objections raised by the Mansholt plan, the Six had asked the Commission to revise its proposals. These revised proposals were presented on 12 May 1964. The entry into effect of common cereal prices was postponed to two years but the price range was not significantly altered. However, the Six still could not agree and decided to postpone a decision until 15 December 1964. The Federal government had won a six-month reprieve but it was increasingly isolated in the Community. In fact, the revisions made by the Commission alleviated some of the French reservations. For the French Agriculture Ministry, it had become advantageous to "modérer nos réserves à l'égard du plan Mansholt, sinon même à le soutenir plus nettement que

38. AD/MAE, PD-OW, vol.36, Note a/s les prix agricoles dans la CEE en 1964-1965, Paris, 12.03.1964; Note sur le plan Mansholt, 24.03.1964. See also C. de GAULLE, Lettres, notes et carnets 1964-1966, Plon, Paris, 1987, p.33.

39. Archives nationales [AN], $5 \mathrm{AG} 1 / 54$, note a/s de l'audience des dirigeants agricoles et des problèmes actuels de l'agriculture française (no date).

40. AD/MAE, DECE 1961-1969, vol.1151, Margerie à MAE, 23.03.1964; PAAA, B 150, Bd.25, Lahr betr. Getreidepreis in der EWG, 20.03.1964. See also H. MÜLLER-ROSCHACH, Die deutsche Europapolitik 1949-1977. Eine politische Chronik, Europa Union Verlag, Bonn, 1980, pp.144-145.

41. AD/MAE, PD-OW, vol.3, Note a/s conversations Wormser-Lahr, 27.05.1964; AAPD, 1964 II, p. 1161. 
nous ne l'avons fait jusqu'ici". ${ }^{42}$ The French had realized that it would speed up the realization of the common agricultural market and insure the renewal of the financial regulation after 1 July 1966 without placing France in the uncomfortable position of having to make concessions during the Kennedy Round.

Anxious that their opposition would give the French a pretext to delay negotiations in Geneva, the Germans sought to find a deal with Paris. ${ }^{43}$ In July, Lahr thus tried to negotiate a fictive cereal price with Wormser. ${ }^{44}$ But the French did not want to get into bilateral talks that would exonerate the Federal government of the effects of its delaying tactic on the GATT negotiations - in fact, the definition of a common cereal price was a crucial element of the EEC's negotiating position.

Bonn's unaltered opposition increasingly strained Franco-German relations, even though the deterioration was also a result of the failed July 1964 summit meeting. Over the autumn months, various declarations of Germans officials implied that the Federal Republic would not be able to agree to a common cereal price by December 15. Margerie accurately foresaw a Franco-German confrontation on the cereal price issue.

The German reluctance to fulfil agricultural commitments prompted the French government to outline France's "résolution catégorique" 45 to obtain the completion of the CAP even at the expense of a Community crisis. On 21 October, Alain Peyrefitte, the government's spokesperson, announced that

"la France cesserait de participer à la Communauté européenne si le marché commun agricole ne s'organisait pas comme il avait été convenu qu'il s'organiserait". ${ }^{46}$

Domestic reasons also accounted for this more aggressive stance. Confronted with farm protests and a growing opposition to de Gaulle's agricultural policy, the French government pushed for the speedy adoption of a common cereal price because he could make Brussels responsible for the resulting increase of prices. ${ }^{47}$ If Bonn did not take de Gaulle's threat too seriously, Hallstein did. Shortly after Peyrefitte's declarations, he and the German Commissioner Hans von der Groeben travelled to Bonn and urged Erhard to make a decision on the cereal price.

De Gaulle's bullying efforts and the Commission's pressures, along with the growing isolation of Germany in the EEC, eventually forced Erhard to favour political and economic interests over domestic considerations. ${ }^{48}$ The German Chancellor

42. AD/MAE, DECE, vol.1151, Note a/s du plan Mansholt (no date).

43. PAAA, B 20, Bd.890, Aufzeichnung betr. St.S.-Besprechung am 23.06. 1964. Bilaterale Getreidepreisverhandlungen Deutschland-Frankreich, Bonn, 22.06.1964.

44. AD/MAE, PD-OW, vol.3, Note, 17.07.1964; PAAA, B 2, B 131, Aufzeichnung von Lahr betr. deutsch-französische Konsultation/Gespräch mit Generaldirektor Wormser, 24.07.1964.

45. Centre des archives diplomatiques de Nantes [CADN], vol.239, X. du Cauze de Nazelle to E. Bömcke, 24.10.1964.

46. Déclaration de M. Peyrefitte, 21 octobre 1964, in: L'année politique en Europe, 1965, p.104. See also A. PEYREFITTE, C'était de Gaulle ..., II, op.cit., pp.265-266.

47. A. PEYREFITTE, C'était de Gaulle ..., II, op.cit., pp.268-269.

48. AAPD, 1964 II, Dok.301, pp.1199-1200. 
charged Konrad Adenauer with negotiating a Franco-German compromise during his visit to Paris in early November 1964 that made Bonn's agreement to a common cereal price conditional on the enforcement of the price on 1 July 1967 and on hefty compensations for the German farmers' loss of income. ${ }^{49}$ Yet, Paris wanted more than promises as it had come to distrust Bonn.

A month before the beginning of the agricultural negotiations, Erhard decided to bypass Schwarz and started negotiating with Rehwinkel the conditions of the DBV's agreement to a common cereal price. On 24 November, the Federal Cabinet accepted the Mansholt plan under certain conditions such as the adjournment of the coming into effect of cereal prices by July 1967 and substantial financial compensations, and made it conditional on a package deal including the internal development of the Community (customs union and political union) and external relations (Kennedy Round) ${ }^{50}$ Yet, the French rejected such a "solution globale". ${ }^{51}$ They could not accept that the German government, which they thought was largely responsible for the deadlock, could raise conditions. Hence, the Erhard-Rehwinkel arrangement did not solve any of the Franco-German disagreements.

As a result, the French and German delegations clashed in Brussels when negotiations opened on 14 December. ${ }^{52}$ Mansholt was charged with the task of drawing a "take-it-or-leave-it" 53 package deal that, however, did not change the price fixed for cereals. In the early morning of 15 December, after a long "nuit du blé", the Six finally agreed on a common cereal price, set at $425 \mathrm{DM} / \mathrm{t}$ and effective on 1 July 1967.54 Despite stark critics from the DBV, the agreement was confirmed by the Federal Cabinet the following day. This "grand succès" 55 was only possible because Erhard intended it to be a decisive element for the continuation of European integration ${ }^{56}$ and for the improvement of relations between Paris and Bonn. ${ }^{57}$ Despite the high level of the common cereal price and the foreseeable financial implications of the compensations allocated to Germany, satisfaction predominated on both sides of the Rhine. If, according to Couve de Murville, the significance of the agreement was "économiquement discutable", 58 its importance was essentially political. But de Gaulle was already targeting his next objective:

49. PAAA, B 150, Bd.40, Aufzeichnung von Carstens betr. Getreidepreis, 09.11.1964.

50. PAAA, B 130, B 2224, Lahr to Washington, St.S.-2198/64, 25.11.1964; AD/MAE, PD-OW, vol.3, Note a/s du plan Mansholt, 27.11.1964.

51. AD/MAE, PD-OW vol. 3, Note a/s entretien Wormser-Lahr du 27.11 et 27.11.1964.

52. AD/MAE, EU 1961-1970, s/s RFA, vol.1651, TGD de Lucet, Paris, 14.12.1964.

53. S. MANSHOLT, La crise. Conversations avec Janine Delauney, Stock, Paris, 1974, p.114.

54. For a detailed account of the multilateral negotiations, see A.C.L. KNUDSEN, Creating the Common Agricultural Policy: The Story of Cereal Price, in: W. LOTH, Crises and Compromises. The European Project 1963-1969, Nomos, Baden-Baden, 2001, pp.131-154.

55. Rolf LAHR, Zeuge von Fall und Aufstieg. Private Briefe 1934-1974, Albrecht Knaus Verlag, Hamburg, 1981, p.412.

56. PAAA, B 1, Bd.212, St.S. Lahr betr. EWG-Getreidepreis an alle diplomatischen und berufskonsularischen Vertretungen der BRD im Ausland, 19.12.1964.

57. H. OSTERHELD, op.cit., p.123; H. MÜLLER-ROSCHACH, op.cit., p.150.

58. M. COUVE DE MURVILLE, op.cit., p.325. 
"il y a des règlements à faire sur différent produits et surtout le règlement financier; tant qu'il n'est pas adopté, rien de définitif n'est obtenu". 59

\section{The Empty Chair Crisis of 1965}

With the decisions of December 1963 and 1964, common market organizations for the most important commodities were established. There remained, however, the question of the financing of the CAP. In January 1962, the Six had decided that national contributions would fund the CAP budget until 1 July 1966. From January 1970 on, the European Agricultural Guidance and Guarantee Fund (EAGGF) would be funded by the Community's own resources. The Six had asked the Commission to draw up proposals for the financing of the CAP from July 1966 to January 1970. Furthermore, the expiration date of the CAP's financing regulation coincided with a change in the voting system in the Council of Ministers where qualified majority voting would replace unanimity.

Hallstein presented the Commission's proposals on 23 March 1965 in Strasbourg. They triggered one of the most serious crises of the Community as the future financing of the CAP was linked with an important increase of the Commission's and of the European Parliament's competencies. ${ }^{60}$ In fact, the Commission proposed to replace the national contributions of the member states by own resources of the Community that would be funded from the export duties and import levies. Accordingly, the budgetary powers of the European Parliament would have to be increased in order to control these new resources. For the financing of the CAP, the Commission suggested a two-stage procedure. In the first stage, through to 30 June 1967, the CAP would continue to be financed by national contributions according to an allocation key that would be identical for France and Germany. The second stage would start on 1 July 1967 with the coming into effect of the common agricultural market.

The French reaction to the Commission's proposals was largely negative. President de Gaulle could not accept the strengthening of supranational institutions such as the Commission, "cet aréopage technocratique, apatride and irresponsable", ${ }^{61}$ to the detriment of intergovernmental bodies such as the Council of Ministers. De Gaulle rejected the Commission's proposal on two grounds. First, the proposals had been

59. A. PEYREFITTE, C'était de Gaulle ..., II, op.cit., p.272.

60. For a general account of the empty chair crisis, see J. NEWHOUSE, Collision in Brussels. The Common Market Crisis of 30 June 1965, Norton, New York, 1967; M. CAMPS, European Unification in the Sixties. From the Veto to the Crisis, McGraw-Hill, New York, 1966; N.P. LUDLOW, The European Community and the Crises ..., op.cit., chaps.2-4. For detailed studies on the Commission's strategy in the run-up to the crisis, see P. BAJON, The European Commissioners and the Empty Chair Crisis, in: Journal of European Integration History, 2(2009), pp.105-123; L. WARLOUZET, Relancer la CEE avant la chaise vide: Néo-functionnalistes vs. fédéralistes au sein de la Commission européenne, in: Journal of European Integration History, 1(2008).

61. C. de GAULLE, Discours et Messages, vol.IV, Plon, Paris, 1970, p.379. 
presented to the European Parliament without prior consultation of the member states. Second, and most importantly, he opposed the strengthening of supranationality through the increase of the competencies of the European Parliament and the Commission. De Gaulle's reservations towards the Commission were not new, but tensions between the two former allies had increased since the beginning of $1965 .{ }^{62}$ For the Commission, 1965 seemed favourable to launch an ambitious initiative given the French presidential elections at the end of the year, and de Gaulle's interest to complete the CAP. Hallstein thus believed he could force the French President to accept sovereignty transfers to the European institutions in exchange of the completion of the CAP. ${ }^{63}$ In Bonn, the Federal authorities faced a dilemma. On the one hand, they supported the Commission's proposals to strengthen the European Parliament, which they had repeatedly promoted. On the other hand, Bonn was not ready to agree to a five-year financial regulation and lose all means to pressure France on the Kennedy Round. The resolution adopted by the Bundestag on 30 June 1965 mirrored this ambivalent attitude. ${ }^{64}$

Despite different viewpoints on the content of the Commission's proposals, Paris and Bonn shared some criticisms. For instance, both capitals disagreed with the allocation to the Community of both levies and duties which would exceed by far what the Community needed to finance the CAP. Moreover, they disagreed with the subsequent strengthening of the competencies of the Commission, which would de facto administer the Community. Paris thus remained relatively confident in the outcome of the June negotiations on the financial regulation, not least because de Gaulle was once again linking his participation in a summit meeting in Venice to discuss the proposals presented by Erhard in the autumn of 1964 on the deepening of political cooperation to the adoption of the financial regulation. He expected Erhard would once again submit to his conditions. Surprisingly, even the substitution of unanimity by qualified majority voting did not seem to worry Oliver Wormser. ${ }^{65}$

But de Gaulle underestimated the increasing frustration of the Federal government. The agricultural marathons of 1963 and 1964 had been a "politisches Trauma"66 that hardened positions in Bonn. Erhard was no longer willing to give in to Gaullist blackmailing and rejected de Gaulle's "reciprocal prerequisites", namely the

62. See W. LOTH, Hallstein und de Gaulle: Die verhängnisvolle Konfrontation, in: W. LOTH, W. WALLACE, W. WESSELS (Hrsg.), Walter Hallstein. Der vergessene Europäer, Europa Union Verlag, Bonn, 1995, pp.171-202; W. LOTH, Les implications du conflit Hallstein-de Gaulle en 1965, in: M.-T. BITSCH, W. LOTH, R. POIDEVIN (dir.), Institutions européennes et identités européenne, Bruylant, Bruxelles,1998, pp.401-418.

63. See W. LOTH, Français et Allemands dans la crise institutionelle de 1965, in: M.-T. BITSCH, Le couple France-Allemagne et les institutions européennes, Bruylant, Bruxelles, 2001, pp.229-243; M. SCHÖNWALD, W. Hallstein and the Empty Chair Crisis 1965/66, in: W. LOTH, Crises and Compromises ..., op.cit., pp.157-171.

64. AD/MAE, DECE, vol.1112, Résolution du Bundestag relative aux propositions de la CEE, 30.06.1965. See also Europa-Archiv 20 (1965), p.D 427.

65. AD/MAE, DECE, vol.1111, Note a/s des règles de majorité dans le traité de Rome, 21.05.1965.

66. J. ERTL, Agrarpolitik ohne Illusionen. Politische und persönliche Erfahrungen, Verlag A. Strothe, Frankfurt/Main, 1985, p.77. 
French promise of supporting the re-launch of political talks between the Six in exchange for a German agreement on the CAP. The German Chancellor did not understand that these prerequisites were not simply a means of pressure but represented in de Gaulle's mind essential conditions for the political and economic unity of Europe. This rejects Moravcsik's argument according to which commercial and not political interests were a paramount motivation for French policy in Europe. ${ }^{67}$ Erhard thought that his repeated compliance with the French agricultural demands had given him the right to expect "un appui aux désirs allemands, particulièrement dans le domaine de la cooperation politique". ${ }^{68}$ As a result, Erhard was no longer willing to make unilateral concessions to Paris. The French leader thus misjudged the Federal Chancellor's determination to wait

"mit unserer Zustimmung zu der in erster Linie im französischen Interesse liegenden Agrarpolitik [...], bis wir die französische Zustimmung der Zollunion [...] erreicht haben". ${ }^{69}$

The hardening of the German position also coincided with the re-degradation of bilateral relations after the summit meeting of Rambouillet of January 1965 as a result of de Gaulle's cancellation of his participation in the Venice summit.

On 24 May 1965, a double meeting took place in Bonn between the Ministers of Foreign Affairs and the officials in charge of Economic Affairs to discuss the Commission's proposal. Despite a good atmosphere, the French and German positions remained divergent. Hence, the summit meeting of 11-12 June was the last possibility to forge a bilateral compromise on the financial regulation of the CAP and the questions raised by the Commission's proposals.

At the end of the first day of the Franco-German summit, both the French and the German delegations were optimistic. Indeed, a compromise seemed possible on the budgetary powers of the European Parliament. ${ }^{70}$ Although the application period of the financial regulation, the coverage of expenditures and the allocation of costs in the Community remained problematic, ${ }^{71}$ Paris and Bonn were willing to find an arrangement. Nevertheless, in the closing session on 12 June, Chancellor Erhard read a statement written by Lahr, which called into question the rapprochement of positions achieved before. In particular, the document stressed that the financial regulation to be adopted at the end of June would be valid one year instead of five years, whereas this was a prerequisite for Paris. The French and German experts convened

67. A. MORAVSCSIK, op.cit.

68. AN, 5AG1/162, Note, Paris, 1965.

69. PAAA, B 150, Bd.52, Aufzeichnung betr. Darstellung und Analyse der derzeitigen französischen Außenpolitik und Vorschläge für unser Verhalten, 11.05.1965.

70. AN, 5AG1/162, Entretien des ministres des affaires étrangères à Bonn, 11.06.1965; AAPD, 1965 II, pp.1012-1016; AD/MAE, DECE, vol.1111, AN, 5AG1/162, Conversation entre MM. le Premier ministre, le ministre des Finances et le secrétaire d'Etat à l'économie de la République fédérale, 12.06.1965; AAPD, 1965 II, Dok.245, pp.1026-1027.

71. AN, 5AG1/162, Séance plénière du 11.06.1965, PAAA, B 20, Bd.1320, Aufzeichnung des BMF betr. französischer Vorschlag vorgebracht bei den deutschen-französischen Besprechungen am 11./12.06.1965, 14.06.1965. 
for a working lunch but could not reach an agreement. By refusing to negotiate a fiveyear regulation, German diplomats hoped to persuade Paris to continue the discussions after 30 June while French diplomats insisted that a five-year regulation should be adopted no later than 30 June. On the plane back to France, the French President did not hide his frustration at the German refusal. ${ }^{72}$

The failure of the Franco-German discussions accounted for the change of strategy of the French delegation at the Council of Minister of 13-15 June 1965. Couve de Murville made a proposal combining firmness on the principles (the adoption of the financial regulation by June 30) but flexibility on certain negotiable points (for instance the gradual allocation of levies and duties to the Community budget, and the allocation key). With these proposals, Paris made a gesture towards those partners, including Germany, who were afraid of paying the bigger share to the Community budget. A Franco-German rapprochement was reached on two main points. The Germans accepted to shelve the question of the strengthening of the European Parliament, and they also seemingly agreed to a five-year financial regulation. ${ }^{73}$ The visit of Lahr confirmed the bilateral rapprochement. ${ }^{74}$ Back in Bonn, Lahr stated that "eine erfreuliche Übereinstimmung in wesentlichen Punkten" 75 had been reached. Wormser even believed "on avait décidé à Bonn de s'aligner sur les positions françaises telles qu'elles ont été définies à Bruxelles le 15 juin". ${ }^{76}$ Yet, this last-minute FrancoGerman compromise did not prevent the outbreak of the empty chair crisis.

Based on the Wormser-Lahr agreement, the French required the adoption of a five-year financial regulation during the Council of Minister of 29-30 June 1965. Negotiations were hard-fought but not necessarily condemned to failure. However, Schröder's unexpected change of mind on the competencies of the European Parliament, along with the dilatory attitude of the Italians and the Dutch, forced Couve de Murville, who held the rotating Presidency of the Council, to interrupt the talks. The following day, Alain Peyrefitte announced that France would draw "les consequences économiques, politiques et juridiques de la situation". ${ }^{77}$ On July 6, the French permanent representative was called back to Paris. France's seat in Brussels was empty. The lack of genuine Franco-German cooperation and the failure of the Elysée Treaty were thus one of the causes of the crisis.

\section{Manfred Klaiber, German Ambassador to Paris, recommended}

"alles zu unterlassen, was den Konflikt zwischen Frankreich und den übrigen Fünf zu einem deutsch-französischen Konflikt potenzieren könnte". ${ }^{78}$

72. A. PEYREFITTE, C'était de Gaulle ..., II, op.cit., p.287.

73. AD/MAE, PD-OW, vol.3, Note a/s des affaires européennes (no date).

74. AD/MAE, Pactes, vol.340, Wormser to Bonn and Delfra Bruxelles, Paris, 23.06.1965.

75. PAAA, B 2, Bd.129, Auszug aus dem Parlamentsprotokoll vom 2.07.1965.

76. AD/MAE, PD-OW, vol.3, Note de Wormser a/s entretien Wormser-Lahr du 22 juin, 23.06.1965.

77. AD/MAE, PD-OW, vol.36, TGD a/s rupture des négociations de Bruxelles sur le financement de la PAC, 05.07.1965; PAAA, B 150, Bd.36, Klaiber to the AA betr. französische Ministerratssitzung, 01.07.1965.

78. PAAA, B 150, Bd. 56, Klaiber to the AA betr. Brüsseler Krise, 02.07.1965. 
Given the pressure from French farmers for the completion of the CAP and the presidential elections at the end of 1965, he expected that France would soon be back in Brussels. Despite his warnings, hard-liners like Schröder and Lahr prevailed in Bonn. They believed that the crisis was not the result of a Franco-German disagreement and that a solution had to be negotiated on a Community not a bilateral level. Hence, they refused to use the consultation framework of the Elysée treaty.

In Paris, French diplomats were very critical of Germany's attitude during the Council of Ministers meeting. Paris felt that Bonn had not only betrayed what had been agreed bilaterally, ${ }^{79}$ but had tried to "exploiter la situation pour faire accepter un certain nombre de demandes reconventionnelles". ${ }^{80}$ The German attitude during the negotiations had increased Paris' mistrust towards Bonn. Therefore, the argument of Bonn's "treachery" was not just rhetorical or simply designed to legitimate the French boycott, but it also stressed the profound damages left by the constant degradation of bilateral relations since 1964 and by prior bilateral conflicts over agriculture. Moreover, previous German manoeuvres to delay the completion of the CAP had convinced de Gaulle that the transition from unanimity to qualified majority voting would jeopardize the completion of the CAP as it would give CAP sceptical partners, including Germany, an opportunity to revise it. Margerie evoked "la crise psychologique provoquée par l'attitude dilatoire de la République fédérale vis-à-vis du Marché commun". ${ }^{81}$ This also explains France's insistence on the adoption of a financial regulation valid for five years, from 1966 to 1970, and not until 1967 as proposed by the Commission, since in 1967 a new regulation would have to be adopted by qualified majority votes. Moreover, the proposals of the Commission gave Paris a unique opportunity to get rid of "toute cette mafia de supranationalistes", to "liquider" majority voting and to return to an organized cooperation among the Six that would "coiffer Bruxelles", ${ }^{82}$ as de Gaulle bluntly exposed in his press conference on 9 September. ${ }^{83}$ Hence, the empty chair crisis was also a political gamble designed to broker a compromise

"qui prenne en compte le plus largement possible les intérests agricoles français et les conceptions politiques du général de Gaulle". ${ }^{4}$

None of de Gaulle's objectives were acceptable to the Germans, however. Even though Bonn did not rule out adjustments to the functions and role of the Commission - as long as its independence was not altered - it refused any formal revision of the Rome Treaty. Nevertheless there existed some room for negotiation since de Gaulle's objective was "une formule resituant le droit de veto pour une question essentielle" 85 rather than a formal revision of the treaties. Accordingly, "le gouvernement

79. AN, 5AG1/48, Projet de TG pour Bonn, 06.07.1965.

80. AD/MAE, PD-OW, vol.36, Note de Wormser A/s de l'Europe des Six, 13.10.1965.

81. AD/MAE, EU 1961-1970, s/s RFA, vol.1696, Rapport de fin de mission de l'ambassadeur R. de Margerie, 03.01.1966.

82. A. PEYREFITTE, C'était de Gaulle ..., II, op.cit., pp.291, 294 and 295.

83. C. de GAULLE, Discours et Messages, op.cit., p.378.

84. PAAA, B 150, Bd. 56, Klaiber to the AA betr. Krise der EWG, 14.07.1965.

85. A. PEYREFITTE, C'était de Gaulle ..., II, op.cit., p.299. 
fédéral ne se refuserait pas pour sa part à un accord interprétatif sur l'application de la règle de la majorité", ${ }^{86}$ that could be elaborated on a bilateral basis. Paris' and Bonn's interests were thus similar. But, Erhard, who had just been re-elected and was forming his new Cabinet, did not want to rush things and left the German delegation without instructions.

During the summer, the consultation framework of the Elysée treaty was not used because Bonn did not want to enter into bilateral talks with Paris and risk to undermine the cohesion of the Five in their opposition to de Gaulle. It was essential for Erhard and the Auswärtiges Amt "dem General als Gemeinschaft gegenüberzutreten". 87 Playing the card of the Community solidarity was important for the Federal government because it did not want to be looking for a "Sonderarrangement" 88 with France. Avoiding bilateral talks presented the additional advantage that Bonn would not be forced to make unilateral concessions to Paris as in 1963 and 1964. In September 1965 , General de Gaulle denounced the "cordiale virtualité" 89 that the treaty had become.

Franco-German consultations finally resumed in the autumn. A meeting between Couve de Murville and Schröder in mid-October did not reach any conclusions. The Auswärtiges Amt did not want "se laisser entraîner dans une procédure de pourparlers bilatéraux" 90 that might sideline the other Community partners. Yet, with the looming French presidential election, Couve de Murville was in favour of a rapid solution to the crisis. In fact, the runoff from the first ballot on 5 December mirrored the growing unpopularity of the empty chair policy among the French electorate. For de Gaulle, it had also become necessary to show that France did not intend to "torpiller" Common Market. The day after de Gaulle's re-election, a Council of Ministers confirmed France's participation in a meeting of the six Foreign Ministers in Luxembourg on 17-18 January 1966. The French had not abandoned any of their demands, but they were ready to negotiate the conditions of their return to Brussels. The end of the empty chair policy, furthermore, appeared essential given the French president's project of withdrawing France from the North Atlantic Treaty Organization (NATO). The Quai d'Orsay was well aware that this would open another front with the EEC partners and that Paris could not deal with two crises at the same time. Therefore, de

86. CADN, Archives rapatriées de l'ambassade de France à Bonn, vol.262, Seydoux à MAE a/s instructions pour la délégation allemande, Bonn, 28.09.1965.

87. AAPD, 1965 II, Dok.269, p.1126. For a detailed account of Germany's position, see Henning TÜRK, 'To face de Gaulle as a Community'. The role of the Federal Republic of Germany during the Empty Chair crisis, in: J.-M. PALAYRET, H. WALLACE, P. WINAND (eds.), Visions, Votes and Vetoes. The Luxembourg Compromise in Historical Perspective, Bruxelles, PIE-Peter Lang, 2006, p.117.

88. Bundesarchiv Koblenz, NL Hallstein, N 1266, Bd.1187, Stichworte für Ihr Gespräch am 15.07.1966, 14.07.1966.

89. C. de GAULLE, Discours et Messages, op.cit., p.385.

90. CADN, vol.262, Seydoux to MAE, 19.11.1965.

91. C. de GAULLE, Discours et Messages, op.cit., pp.422-425. 
Gaulle hoped he could forge a compromise with Bonn on France's return to Brussels to which the other partners would rally. ${ }^{92}$

On 17 January during the first meeting of the Six in Luxembourg, Couve de Murville presented France's conditions for her return to Brussels. The French Minister spoke in favour of a political arrangement, without a revision of the treaties, and explained that voting rules should make sure that a Member State would not be outvoted. But Schröder refused any formula by which the Six would renounce the use of majority voting. Moreover, the so-called Decalogue, which detailed the suggestions for improving the behaviour of the Commission, and the schedule presented by the French delegation also met with strong reservations from the Five. The French were particularly irritated by the systematic opposition of Schröder to their proposals during the two-day Luxembourg meeting. The conflict between France and the Five had taken a bilateral character. The FRG was not willing to compromise because it feared that the postponement of negotiations to a second conference would enable Paris to trick its partners, i.e. to let multilateral negotiations fail in order to seek a bilateral compromise during the Franco-German summit meeting that was to take place shortly thereafter. ${ }^{93}$ German worries were not completely unfounded since de Gaulle had made some overtures to German Ambassador Klaiber after the first Luxembourg conference. ${ }^{94}$

On 28-29 January 1966, the Six met again in Luxembourg in order to redefine relations between the Council and the Commission and to find a solution to the question of majority voting. If an agreement was rapidly made on the first issue, negotiations threatened to stumble over the majority voting issue. Schröder then suggested a solution that was similar to what he had already proposed to Couve de Murville in November. According to this formula, the Six would try to reach a consensus when vital interests of a member state would be at stake. Schröder also added that it would apply to all market regulations that should have been adopted by unanimity before 31 December 1965. Indeed, Bonn wanted to avoid being outvoted on sensitive issues such as agriculture and wished to retain its vote as a means of pressure against Paris. ${ }^{95}$ As Wormser summed up, a compromise was possible but it rested on an ambiguity. ${ }^{96}$ The so-called "Luxembourg Compromise" 97 was eventually a compromise between the French and the German proposals. It limited the practical use of majority voting but it did not rule it out completely. On a Franco-German level, the second Luxembourg conference ended on a positive note that eased tensions. The

92. PAAA, B 150, Bd.67, Klaiber to the AA betr. Gespräch mit de Gaulle, Paris, 02.01.1965; A. PEYREFITTE, C'était de Gaulle ..., III, op.cit., pp.181-182.

93. PAAA, B 150, Bd.67, Lahr betr. Krise der EG/FS von der Botschaft Brüssel, 13.01.1966.

94. PAAA, B 150, Bd.67, Klaiber to the AA betr. Gespräch mit de Gaulle, Paris, 2.01.1965. See also A. PEYREFITTE, C'était de Gaulle ..., III, op.cit., p.182.

95. PAAA, B 20, Bd.1331, Lahr betr. 2. außerordentliche EWG-Ratstagung vom 28./29. Januar 1966 in Luxemburg, 31.01.1966.

96. AD/MAE, DECE, vol.1113, Note a/s entretien avec Lahr, 29.01.1966.

97. For an historical assessment of the Luxembourg compromise, see J.-M. PALEYRET, H. WALLACE, P. WINAND (eds.), op.cit. 
debates were devoid of the acrimony that had characterized the first conference. The Germans did not present themselves as a spokesman for the Five and adopted a more conciliatory attitude that facilitated contacts between the French and German delegations and mutual concessions.

With the Luxembourg Compromise, the Community could return to work. However, Franco-German disagreements had all but disappeared. France still required the swift adoption of the financial regulation before any other outstanding decisions. Yet, according to Schröder, the realization of the Common agricultural market was only acceptable if parallel progress was achieved in the customs union and the Kennedy Round. Bonn thus intended to

"lier le règlement financier, l'avancement des négociations multilatérales du GATT, l'adoption de décisions au moins de principe sur les prix communs, l'achèvement du marché commun agricole, et l'entrée en vigueur simultanée de la libre circulation des produits agricoles et industriels". 98

After several bilateral talks in the course of March and April 1966, ${ }^{99}$ Paris and Bonn sketched a compromise that took into account the four elements of the German package deal and balanced mutual concessions. This compromise, which was drafted in the middle of the NATO crisis, dispelled remaining French doubts about "la volonté des Allemands de faire le Marché commun". ${ }^{100}$ Couve de Murville was even surprised that France's withdrawal from the Atlantic Alliance's military organization did not affect, to a greater extent, the agricultural negotiations. ${ }^{101}$

On 11 May 1966, the Six agreed on a financial regulation for the period 1965-1970 and set the date and conditions in which agricultural and industrial products could be traded freely in the Community. This agreement was largely based on the FrancoGerman compromise. In July, a second accord set the final market regulations and completed the agricultural structure of the Community.

\section{Conclusion}

The making of the CAP was characterized by a series of Franco-German and Community crises, which outlined the power relations within the Franco-German tandem, and the role of Franco-German institutionalized bilateralism in the European Community.

98. AD/MAE, EU 1961-1970, s/s RFA, Seydoux to MAE a/s négociations communautaires, 23.03.1966; PAAA, B 2, Bd.130, Lahr betr. Agrarfinanzierung, (no date).

99. PAAA, B 150, Bd.54, Lahr betr. deutsch-französische Konsultation der Außenminister in Bonn/ EWG-Fragen, 19.03.1966; AD/MAE, PD-OW, vol.3, Note a/s entretien avec Lahr, 26.03.1966; PAAA, B 2, Bd.130, Lahr betr. Konsultationen mit Generaldirektor Wormser, 01.04.1966.

100. AD/MAE, DECE, vol.1114, Note a/s du Conseil des 4 et 5 avril 1966 (no date).

101. A. PEYREFITTE, C'était de Gaulle ..., III, op.cit., p.185. 
Franco-German agricultural conflicts in the first half of the 1960s exemplify how the De Gaulle-Erhard relationship worked. Two main factors account for the successful conclusion of the agricultural marathons of December 1963 and 1964: the successful arbitration of Franco-German disagreements within the institutional framework of the Elysée Treaty that provided a forum, in which Paris and Bonn learned to negotiate and reach compromises, on the one hand, and the successful bullying tactics used by Paris on the other hand. Facing French pressures in December 1963 and an ultimatum in December 1964, Erhard submitted to Paris' bullying tactics and twice agreed to do the necessary financial and political concessions because he did not want to strain relations with Paris to the point of rupture and to isolate Germany. ${ }^{102}$ Franco-German consultation failed in 1965 because mistrust and a hard-line policy jammed the bilateral negotiation mechanisms. Erhard's attempts to delay negotiations, his constant hesitations between conciliation and confrontation discredited him quickly in the eyes of de Gaulle. The Federal authorities had also become suspicious of the French intentions. They believed Paris wanted to delay or bring to failure the Kennedy Round, and resented the use of the GATT negotiations as a means of pressure to force them into agreeing to regulations that were unfavourable to the German agriculture. The Gaullist strategy of "shock and awe" also strengthened the proponents of a firm attitude towards Paris and encouraged Bonn to defend its own economic and political interests more firmly even at the expense of a bilateral crisis. Hence, the empty chair crisis was a "Vertrauenskrise" 103 of the Franco-German couple; but it was also part of a German attempt to re-equilibrate power relations between Paris and Bonn much earlier than usually acknowledged in the literature.

Furthermore, this article sheds light on how both countries were able to shape Community bargains in the agricultural area and hence, more generally, on the role of "special" relationships in European integration. Both countries played a preponderant role in the making of the CAP. The numerous crises that broke out on agricultural matters were not entirely bilateral but had each a strong Franco-German dimension. Accordingly, the Community accords that were struck in the first half of the 1960s all relied to a variable extent on Franco-German compromises. This thus seems to confirm the engine role of both countries that can act either as a motor of European integration when both countries come to an agreement as in December 1963 and 1964, or slow it down, when they cannot find a middle ground as in 1965. Moreover, despite divergent viewpoints on the CAP, France and Germany contributed to shaping the original policy path protective of the farmers' interests. By pushing for the creation of the first Community common policy, an apparent paradox given de Gaulle's opposition to any strengthening of supranationality, France was influential in Europeanizing the existing patterns of national protectionism and creating a type of 'welfare policy' for rich European farmers. ${ }^{104}$ In addition, the high price levels agreed in 1963 and 1964 were necessary to prevent any substantial loss of income

102. AD/MAE, EU 1961-1970, s/s RFA, vol.1662, Note a/s de l'application du traité franco-allemand depuis le 17 septembre 1963, 03.02.1964.

103. AAPD, 1965 II, Dok.201, p.805.

104. On the welfare paradigm, see A.C.L. KNUDSEN, Farmers on Welfare ..., op.cit. 
for German farmers, but resulted in the emergence of surpluses in various sectors, such as milk and cereals. Overproduction created an increasing burden for the EC and national budgets and, in the following decade, threatened to develop into a budgetary crisis. From the late 1960s, the Commission repeatedly tried to reform the policy and correct its increasingly obvious flaws. ${ }^{105}$ Finally, the Franco-German confrontations that characterized the first half of the 1960s did not end with the realization of the common agricultural market in 1967. They remained and still are a recurrent feature of almost every agricultural negotiation.

105. On the reform attempts by the Commission, see the contributions of Katja Seidel, Adrian Kay/ Robert Ackrill and Christopher Elton in this issue. 


\title{
Die europäische Gewerkschaftsbewegung und die Gemeinsame Agrarpolitik (1958-1972): Annäherung an einen neuen Forschungsgegenstand
}

\author{
Rainer FATTMANN
}

\section{Voraussetzungen: \\ Die Gewerkschaften und das Projekt der europäischen Integration}

Schon die Anfänge der Europäischen Bewegung waren durch die aktive Mitarbeit zahlreicher Führungspersönlichkeiten der Freien wie auch der Christlichen Gewerkschaften der sechs Staaten gekennzeichnet, die später die Europäische Gemeinschaft für Kohle und Stahl (EGKS) und dann die Europäische Wirtschafts- sowie die Europäische Atomgemeinschaft bilden sollten. ${ }^{1}$ Viele ihrer Repräsentanten hatten bereits das European Recovery Program und im Zusammenhang damit die Vision einer wirtschaftlichen und politischen Einigung Europas in aller Regel uneingeschränkt, ja nicht selten mit Begeisterung begrüßt. Ein zunehmend integriertes Europa erschien ihnen nicht nur als Garant für einen dauerhaften Frieden in Europa und damit als notwendige Antwort auf die Verheerungen der beiden Weltkriege; die Einigung Europas galt darüber hinaus - jedenfalls in den Augen zentraler Führungspersönlichkeiten sowohl der sozialistisch-sozialdemokratisch geprägten, „freien“ Gewerkschaftsbewegung wie auch ihres christlich orientierten Pendants - als wichtige, wenn nicht unabdingbare Voraussetzung für den wirtschaftlichen Wiederaufbau Europas und das wirtschaftliche und soziale Wohlergehen der Arbeiterschaft der europäischen Staaten. ${ }^{2}$

Als 1955 Jean Monnet sein „Aktionskomitee für die Vereinigten Staaten von Europa“" aus der Taufe hob, zählten zu den 35 Gründungsmitgliedern des Komitees daher keineswegs zufällig nicht weniger als 14 Gewerkschaftsvertreter, die in ihren Heimatorganisationen ausschließlich hohe und höchste Posten bekleideten. Auch die Finanzierung dieses über jahrzehntelang überaus einflussreichen proeuropäischen

1. Der vorliegende Aufsatz präsentiert einige Ergebnisse eines von der Hans-Böckler-Stiftung geförderten Forschungsprojekts über die Geschichte der „Europäischen Föderation der Gewerkschaften des Lebensmittel-, Genussmittel-, Landwirtschafts- und Tourismussektors (EFFAT) und ihrer Vorläuferorganisationen“. Die Veröffentlichung des gesamten Forschungsberichts ist geplant.

2. Auskunft über die Hilfestellung der Gewerkschaftsbewegung auf dem Weg nach Europa finden sich an mehreren Stellen der Erinnerungen Jean Monnets; vgl. J. MONNET, Mémoires, Fayard, Paris, 1976. Den detailliertesten Überblick über die Rolle der Gewerkschaften als treibende Kräfte des europäischen Einigungsprozesses bietet nach wie vor E. HAAS, The Uniting Europe. Political, Social and Economic Forces 1950-1957, Stanford University Press, Stanford, 1958. 